\title{
British sheep still contaminated by Chernobyl fallout
}

\section{London}

HUNDREDS of thousands of sheep in Britain are still contaminated by radioactive fallout from the Chernobyl nuclear countries have removed restrictions, the British government last week introduced new measures controlling the movement and slaughter of sheep in Wales and Scotland on farms previously designated as safe; restrictions are also still in force in Cumbria in northern England. logged soil by heavy rainfall after the nuclear plant accident has remained accessible to plant roots, with little clay or loam to bind up the radionuclides. The new season's grass and other pasture plants have taken up caesium and effectively concentrated it, so rough-grazing sheep have ingested quantities of radioactivity. More than 500,000 sheep on 564 hill farms are now under restrictions, according to the Ministry of Agriculture, compared to the four million sheep involved in the initial emergency restrictions imposed in June last year.

Experiments are being conducted by the Institute of Terrestrial Ecology into the effects on caesium uptake of applying reactor explosion. Although most other

Caesium washed into the peaty, water-

a clay mineral, such as bentonite. Controlled field experiments have shown that when bentonite is spread onto pasture and consumed by grazing animals, it can absorb caesium in the gut of sheep or cattle. There are, however, practical difficulties in applying bentonite in the high-caesium areas, where grazing animals roam over miles of open fell country. Techniques of hand-feeding bentonite as a slurry are also being studied.

Ministry of Agriculture officials confess to being somewhat surprised at the continuing high levels of caesium contamination in the soil and the pasture vegetation. The problem could persist for years, according to Dr John Curtis, head of a ministry team studying the effects of Chernobyl on food and agriculture.

Monitoring of humans in affected areas has shown extremely low levels of radiation, according to the National Radiological Protection Board (NRPB). Results showed levels of caesium 134 and 137 of 25 microsieverts in highly affected areas, compared to 10 microsieverts in the unaffected area of Oxfordshire.

The limit of radioactivity for sheep being used by government inspectors is 1,000 becquerels per kilogram, in spite of

\section{"Another Chernobyl" in the Ukraine?}

\section{London}

A LEAding Ukranian writer, Oles' Honchar, has called for action to stop what he describes as a "second Chernobyl". In radio and press interviews celebrating the rehabilitation of his controversial novel of the 1960s, The Cathedral, Honchar spoke forcefully about a "collective letter" just issued by citizens of Cherkassy Oblast', outlining a classic example of bureaucratic confusion and bad planning. It was decided, he said, to build a coal-fired power station on the Dnieper, but then it was found that transporting the coal to the chosen site would not be cost-effective. So the station was redesigned to run on fueloil, piped in from the Kremenchug refinery. Only after the outlay of vast sums of money was it realized that the oil would not flow in the pipelines in the winter, so the station was then redesigned for nuclear power. This, Honchar said, was in spite of the fact that the area is densely populated and there were no proper guarantees given against pollution of the Dnieper, which is the principal source of water for the southern Ukranian industrial belt.

There is considerable opposition to the scheme from scientists, Honchar said, and the official go-ahead for the plans has not yet been given. Nevertheless, the All-Union
Nuclear Power Construction Unit is already "frantically" at work, transferring the population of several villages and tearing down architectural and historical relics. The site of the proposed station is Chyhyryn, the capital of the independent Ukranian Cossack state of the seventeenth and eigthteenth centuries, an area that is virtually an open-air museum "where

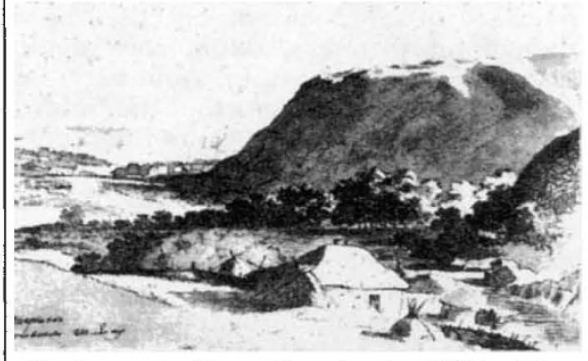
Chyhyryn, by Taras Shevchenko (1814-61).

every step echoes the history of the people", and where many of the relics schedules for demolition were portrayed in the writings and paintings of the Ukranian national poet, Taras Shevenko. Honchar's protests and criticisms have now been supported and amplified by other Ukranian writers, including the exdissident Vasyl Zakenarchenko. Vera Rich the opinion of some scientists that 9,000 becquerels per kilogram, the limit originally recommended by NRPB, would be more appropriate. The lower limit is in line with other European Economic Community (EEC) countries.

The EEC is considering new radioactivity limits to replace the Chernobyl emergency limits which expire in October. The European Commission had recommended caesium limits of 1,000 becquerels per kilogram for dairy products, 1,250 for other foodstuffs, 800 for drinking water and 2,500 for animal feedstocks. Other recommended limits for dairy products are 500 for isotopes of iodine and Strontium, and 20 for isotopes of plutonium and other alpha-emitting nuclides; for other foodstuffs, 3,000 for iodine and strontium, 80 for plutonium; and for drinking water, 400 for iodine and strontium, 10 for plutonium.

Kathy Johnston

\section{UK looks East at Chernobyl}

\section{London}

ENGINEERS of the UK Atomic Energy Authority (AEA) have devised the name "positive scram" to describe the sequence of events that put paid to one of the nuclear reactors at Chernobyl in the Ukraine a year ago, but think it unlikely that there will be a recurrence.

The British post-mortem on Chernobyl, discreetly made public on the eve of the anniversay of last year's debriefing conference at Vienna, is apparently one of several conducted by authorities in countries such as the United States, Canada and France. "Scram" is the name for the process of shutting down a reactor in a hurry, and "positive scram" that for the circumstances in which emergency action has an effect opposite to that intended.

Atomic Energy of Canada Ltd seems to have taken much of the initiative in deciding what went wrong last year. The root cause of the accident, it seems to be agreed, is a sequence of errors and illegal procedures so surprising that the British AEA believes they may have been habitual. The net effect was that the reactor was operating in a condition far from normal, in which the excess reactivity of a thermal reactor derives from the 0.7 per cent of all neutrons originating from fission daughters of uranium-235 with a delay of some seconds.

The decision of the operators at Chernobyl to withdraw one batch of control rods beyond their normal range is also reckoned to have been a serious contributory cause of the accident. But John Gittus of the AEA believes that the changes made to Soviet reactors since the accident will have sufficed to make plants of that kind safe. 